\title{
Effect of Human Polymorphonuclear and Mononuclear Leukocytes on Chromosomal and Plasmid DNA of Escherichia Coli
}

\section{Role of Acid DNase}

\author{
Maja Rozenberg-Arska, Jos A. G. van Strijp, \\ Wiel P. M. Hoekstra, and Jan Verhoef \\ Department of Clinical Bacteriology, University Hospital, \\ Catharijnesingel 101; Department of Microbiology, \\ Catharijnesingel 59; Department of Molecular Cell Biology, \\ Padualaan 8, Utrecht, The Netherlands
}

A morphonuclear and tant host resistance factors against invading microorganisms. Evidence showing that killing is rapidly followed by degradation of bacterial components is limited. Therefore, we studied the fate of Escherichia coli DNA following phagocytosis of $E$. coli by polymorphonuclear and mononuclear leukocytes. $\left[{ }^{3} \mathrm{H}\right]$ thymidine-labeled, unencapsulated E. coli $\mathrm{PC} 2166$ and $E$. coli $048 \mathrm{~K} 1$ were incubated in serum, washed, and added to leukocytes. Uptake and killing of the bacteria and degradation of DNA were measured. Although phagocytosis and killing by mononuclear leukocytes was less efficient than that by polymorphonuclear leukocytes, only mononuclear leukocytes were able to degrade E. coli PC2166 DNA. Within 2 h, 60\% of the radioactivity added to mononuclear leukocytes was released into the supernate, of which $40 \%$ was acid soluble. DNA of $E$. coli $048 \mathrm{~K} 1$ was not degraded. To further analyze the capacity of mononuclear leukocytes to degrade $E$. coli DNA, chromosomal and plasmid DNA was isolated from ingested bacteria and subjected to agarose gelelectrophoresis. Only chromosomal DNA was degraded after phagocytosis. Plasmid DNA of $E$. coli carrying a gene coding for ampicillin resistance remained intact for a 2-h period after ingestion, and was still able to transform recipient $E$. coli cells after this period.

Address correspondence to Dr. Rozenberg-Arska, Department of Clinical Bacteriology, University Hospital, Department of Clinical Bacteriology, 3511 GV Utrecht.

Received for publication 1 September 1983 and in revised form 30 December 1983.

J. Clin. Invest.

(C) The American Society for Clinical Investigation, Inc. $0021-9738 / 84 / 05 / 1254 / 09 \quad \$ 1.00$

Volume 73, May 1984, 1254-1262
Although we observed no DNA degradation during phagocytosis by polymorphonuclear leukocytes, lysates of both polymorphonuclear and mononuclear leukocytes contained acid-DNase activity with a $\mathrm{pH}$ optimum of 4.9. However, the DNase activity of mononuclear leukocytes was 20 times higher than that of polymorphonuclear leukocytes. No difference was observed between DNase activity from polymorphonuclear and mononuclear leukocytes from a chronic granulomatous disease patient with DNase activity from control polymorphonuclear and mononuclear leukocytes.

\section{Introduction}

The bacteriolytic activity of serum and the phagocytic capacity by polymorphonuclear (PMN) ${ }^{1}$ and mononuclear leukocytes (MN) are important host-resistance factors against invading microorganisms (1-4). Many bacteria become opsonized in serum and are recognized by phagocytic cells (4-8). After ingestion, most of the microorganisms are rapidly killed by the oxygendependent and oxygen-independent antimicrobial systems of the phagocytes $(9-13)$.

Destruction of some but not all bacteria can be observed within intact leukocytes or during exposure of the bacteria to leukocyte lysates (14-19). Cohn (18), Patriarca et al. (20), and Elsbach et al. (19) found that during phagocytosis, $\sim 50 \%$ of radiolabeled bacterial protein, RNA, and peptidoglycan is converted into acid-soluble products, compared with only $10 \%$ hydrolysis of the phospholipids. Not much is known about degradation of DNA by PMN and MN. Elsbach et al. (19) did not observe any degradation of Escherichia coli DNA after ingestion

1. Abbreviations used in this paper: CGD, chronic granulomatous disease; cfu, colony-forming unit; Gel-HBSS, Hank's balanced salt solution with gelatin; MN, mononuclear leukocyte; PMN, polymorphonuclear leukocyte; TCA, trichloroacetic acid. 
of $E$. coli by rabbit PMN. Using ${ }^{3} \mathrm{H}$-labeled DNA-anti-DNA complexes, Lamers (21) found that degradation of phagocytized DNA-anti-DNA complexes occurred only in MN but not in PMN.

Despite the absence of significant breakdown of bacterial DNA in PMN, it is possible that bacterial DNA is denaturated after ingestion and digested to large fragments that are still acidprecipitable. Therefore, we studied the fate of chromosomal and plasmid DNA following phagocytosis of $E$. coli strains by measuring the size of DNA breakdown products and by studying the effect of PMN and MN on the capacity of $E$. coli DNA to transform $E$. coli acceptor cells. We found that bacterial chromosomal DNA was only degraded by MN. Neither PMN nor MN degraded plasmid DNA. Although the amount of acid DNase was only $\sim 1 / 20$ of that of $M N$, acid DNase was also detectable in PMN.

To evaluate whether toxic oxygen species (produced during the respiratory burst of the phagocytes) also contribute to the degradation of DNA, we studied the fate of bacterial DNA after phagocytosis of E. coli PC2166 (RSF 1030) by PMN and MN isolated from a patient with chronic granulomatous disease (CGD). No difference in the rate of degradation of DNA by $\mathrm{MN}$ from healthy donors and by those isolated from a patient with CGD was observed.

\section{Methods}

Bacteria. E. coli K12 PC2166 (RSF 1030), harbouring a plasmid coding for ampicillin resistance $\left(5.5 \times 10^{6} \mathrm{~mol} \mathrm{wt}\right), E$. coli $\mathrm{K} 12-\mathrm{C} 600, E$. coli AM $1095\left(\mathrm{Rec}^{+}, \mathrm{Leu}^{-}\right)$, and the encapsulated E. coli 0.48: $\mathrm{K} 1$ (a clinical isolate) were used. $\mathrm{K}$ antigen was determined by the hemagglutination inhibition technique of Glynn and Howard (22). KI antigen was also detected by countercurrent immunoelectrophoresis (23) with meningococcal group b antiserum (The Wellcome Research Laboratories, Beckenham, Kent, England) as reference antiserum.

Radioactive labeling. E. coli $\mathrm{PC} 2166$ (RSF 1030) and E. coli 048:K1 were inoculated from a blood-agar plate into $5 \mathrm{ml}$ of Mueller-Hinton broth (Difco Laboratories Inc., Detroit, MI) containing $0.02 \mathrm{mCi}$ thymidine-methyl- ${ }^{3} \mathrm{H}$ (5 $\mathrm{Ci} / \mathrm{mmol}$, sp act; The Radiochemical Centre, Amersham, Buckinghamshire, England) and $1.25 \mathrm{mg}$ of deoxyadenosine (British Drug House Chemicals Ltd., Poole, Dorset, England). After 18 $\mathrm{h}$ of incubation at $37^{\circ} \mathrm{C}$, the bacteria were washed three times with phosphate-buffered saline (PBS; pH 7.4) and adjusted to a final concentration of $10^{9}$ colony-forming units (cfu) per milliliter with a KlettSummerson photoelectric colorimeter that was standardized by a pourplate method (24).

Serum. Serum from 10 healthy donors was pooled and stored in small portions at $-70^{\circ} \mathrm{C}$. For opsonization of $E$. coli $048: \mathrm{K} 1$, rabbit hyperimmune serum was used. This serum was prepared as follows: $E$ coli $048: \mathrm{K} 1$ was grown overnight at $37^{\circ} \mathrm{C}$ in Mueller-Hinton broth (Difco Laboratories Inc.) washed in PBS, and adjusted to a concentration of $10^{10} \mathrm{cfu} / \mathrm{ml}$ PBS. E. coli $048: \mathrm{K} 1$ was treated with formalin to keep the $\mathrm{K}$ antigen intact (25). This vaccine was stored at $-70^{\circ} \mathrm{C}$ and thawed just before use. New Zealand rabbits (4-6 kg) were subjected to the following immunization schedule: day $1,0.1 \mathrm{ml}$ of vaccine intravenously; day $4,0.2 \mathrm{ml}$ i.v.; day $7,0.3 \mathrm{ml}$ i.v.; day $11,0.3 \mathrm{ml}$ i.v.; day $14,0.4 \mathrm{ml}$ i.v.; day $30,0.5 \mathrm{ml}$ i.v. $1 \mathrm{wk}$ after the last injection the rabbits were bled by heart puncture; serum was collected and stored in 1-ml volumes at $-70^{\circ} \mathrm{C}$ until use. Normal rabbit serum was collected from five normal, nonimmunized rabbits, pooled, and stored at $-70^{\circ} \mathrm{C}$.

Sera samples were thawed shortly before use and diluted in Hank's balanced salt solution containing $0.1 \%$ gelatin (Gel-HBSS). Antiserum titers were measured by tube agglutination (26) and by an enzymelinked immunosorbent assay modified from Rissing et al. (27) with a formalin-killed $E$. coli $048: \mathrm{K} 1$ suspension containing $2.5 \times 10^{8}$ bacteria as antigen.

Leukocytes. PMN and $\mathrm{MN}$ from healthy donors and from a patient with CGD were isolated by a modification of the method developed by Böyum (28), as described elsewhere (24). Briefly, $100 \mathrm{ml}$ of venous blood from healthy donors was drawn into heparinized syringes ( $10 \mathrm{U}$ of heparin per milliliter of blood) and settled by gravity in $3 \mathrm{ml}$ of $6 \%$ dextran $(70,000 \mathrm{~mol} w t$; Pharmacia Fine Chemicals AB, Uppsala, Sweden) in normal saline $/ 10 \mathrm{ml}$ of blood. The leukocyte-rich plasma was withdrawn, centrifuged at $160 \mathrm{~g}$ for $10 \mathrm{~min}$, and the pellet was resuspended in Eagle's minimal essential medium and layered on a Ficoll-Paque (Pharmacia Fine Chemicals AB). After centrifugation at $160 \mathrm{~g}$ for $35 \mathrm{~min}$, the MN and PMN were removed separately, washed twice in Gel-HBSS, counted, and differentiated. The final leukocyte pellets were adjusted to a concentration of $10^{7} \mathrm{PMN} / \mathrm{ml}$ (the percentage of monocytes in this suspension was always $<3 \%$ ) and $10^{7} \mathrm{MN} / \mathrm{ml}$ (the percentage of lymphocytes in this suspension was always $<10 \%$ ).

Opsonization of E. coli strains. Bacteria were preopsonized by incubating $10^{9} \mathrm{cfu} / \mathrm{ml}$ in $2.5 \%$ ( $\mathrm{vol} / \mathrm{vol}$ ) pooled human serum or $20 \%(\mathrm{vol} /$ vol) rabbit hyperimmune serum for $30 \mathrm{~min}$ at $37^{\circ} \mathrm{C}$. Serum was removed by centrifugation $(15 \mathrm{~min}$ at $1,600 \mathrm{~g})$, and the bacteria were then resuspended in Gel-HBSS to a final concentration of $5 \times 10^{8} \mathrm{cfu} / \mathrm{ml}$.

Measurement of bacterial uptake and killing by PMN and MN leukocytes. Phagocytosis and killing of bacteria by PMN and MN were studied using methods previously described (24). Briefly, $0.3 \mathrm{ml}$ of the suspension of opsonized bacteria $\left(5 \times 10^{8}\right.$ bacteria/ml $)$ was added to $0.3 \mathrm{ml}$ of the PMN or MN suspension $\left(10^{7}\right.$ cells $\left./ \mathrm{ml}\right)$ in each of eight polypropylene vials (Biovials, Beckman Instruments Inc., Fullerton, CA). The mixtures were incubated in a shaking waterbath at $37^{\circ} \mathrm{C}$. After 5 min, phagocytosis was stopped in all vials by adding $3 \mathrm{ml}$ of ice-cold PBS to each of the vials. All vials (except vial 1 ) were centrifuged at $160 \mathrm{~g}$ for $5 \mathrm{~min}$, and the leukocyte pellets were washed three times with ice-cold PBS to remove non-leukocyte-associated bacteria. Vial 1 was used to measure the total radioactivity added. This vial was centrifuged at $1,600 \mathrm{~g}$ for $15 \mathrm{~min}$ and the bacteria and leukocyte pellet was resuspended in $2.5 \mathrm{ml}$ of scintillation liquid (toluene-containing fluoralloy TLA, Beckman Instruments Inc., and 20\% Bio-Solv, Beckman Instruments Inc.). Radioactivity was measured in a Mark II (Nuclear-Chicago Corp., Des Plaines, IL) liquid scintillation counter. The final leukocyte pellet of vial 2 was solubilized in $2.5 \mathrm{ml}$ of scintillation liquid, and the leukocytes associated radioactivity (percentage of uptake after $5 \mathrm{~min}$ ) was measured. The percentage of uptake was expressed according to the following formula: percentage of uptake $=[(\mathrm{cpm}$ in washed phagocytic pellet, $160 \mathrm{~g}) /($ total $\mathrm{cpm})] \times 100$. The pellets in the remaining vials $(3-$ 8) were suspended in $0.3 \mathrm{ml}$ of Gel-HBSS and incubated at $37^{\circ} \mathrm{C}$ for $0,15,30,60,120$, and $180 \mathrm{~min}$, respectively. After the indicated time intervals, $0.7 \mathrm{ml}$ of cold, sterile, distilled water was added to the vials to disrupt the leukocytes. Samples $(100 \mu \mathrm{l})$ from these suspensions were taken to determine the number of viable leukocyte-associated bacteria with a standard pour-plate technique with brain heart infusion agar (Oxoid Ltd., Basingstoke, Hampshire, England). After $18 \mathrm{~h}$ of incubation at $37^{\circ} \mathrm{C}$, the number of colonies present in the mixture were counted. The results are expressed in number of viable intracellular bacteria at the indicated time intervals. 
Release of radioactivity from bacteria phagocytized by $P M N$ and $M N$ leukocytes. To study the release of bacterial DNA during the process of phagocytosis, the remaining mixture in vials 3-8 (900 $\mu \mathrm{l} /$ vial) was used. To measure the release of radioactivity from phagocytized bacteria (as an indication of bacterial degradation), the mixtures were centrifuged at $12,000 \mathrm{~g}$ for $5 \mathrm{~min}$, the pellets and supernates were separated and resuspended in scintillation liquid, and the percentage of radioactivity released at the different time intervals was calculated.

In some experiments, $500 \mu \mathrm{l}$ of bovine pancrease DNase 1 (British Drug House Chemicals, Ltd.) in final concentration of $0.5 \mathrm{mg} / \mathrm{ml}$ in $0.1 \mathrm{M}$ potassium acetate buffer $(\mathrm{pH} 4.9)$ or bovine spleen DNase II (Serva, Feinbiochemica Gmbh \& Co., Heidelberg, Federal Republic of Germany) in final concentration of $0.05 \mathrm{mg} / \mathrm{ml}$ in $0.1 \mathrm{M}$ potassium acetate buffer ( $\mathrm{pH} 4.9$ ) was added to vials 3-8. After $15 \mathrm{~min}$ of incubation, the mixtures were centrifuged at $12,000 \mathrm{~g}$ for $15 \mathrm{~min}$, the pellets and supernates were resuspended in scintillation liquid, and the percentage of radioactivity released was calculated.

Trichloroacetic acid (TCA) procedure. Since oligonucleotides containing more than 16 nucleotides are precipitable by TCA (29), the extent of degradation of DNA was measured with TCA. In a separate experiment, an equal volume $(1 \mathrm{ml})$ of cold $10 \%$ TCA was added to vials 3-8 after disruption of leukocytes by distilled water. After $30 \mathrm{~min}$ at $4^{\circ} \mathrm{C}, 0.2 \mathrm{ml}$ of $1 \%$ bovine serum albumin (BSA) was added as a carrier. The precipitate was centrifuged for $15 \mathrm{~min}$ at $1,900 \mathrm{~g}$, and the pellets and supernates were resuspended separately in scintillation liquid. The percentage of acid-insoluble and acid-soluble radioactivity was calculated in the pellets and supernates, respectively.

Isolation of chromosomal and plasmid DNA from bacteria phagocytized by PMN and MN leukocytes. In each of six biovials, $1 \mathrm{ml}$ of the suspension of opsonized bacteria $\left(5 \times 10^{8} \mathrm{cfu}\right)$ was added to $1 \mathrm{ml}$ of PMN or MN suspensions ( $10^{7}$ cells). After 5 min of incubation at $37^{\circ} \mathrm{C}$ in a shaking waterbath, the vials were centrifuged and the pellets washed as described under measurement of bacterial uptake. The final pellets were resuspended in $1 \mathrm{ml}$ of Gel-HBSS and further incubated at $37^{\circ} \mathrm{C}$ for $0,15,30,60,120$, and $180 \mathrm{~min}$, respectively; after these time intervals plasmid and chromosomal DNA were isolated from the phagocytized bacteria.

Plasmid isolation. Plasmid DNA was isolated with the rapid alkalineextraction procedure described by Birnboim and Doly (30). After disruption by cold distilled water of leukocytes containing phagocytized bacteria, the suspensions were centrifuged at $12,000 \mathrm{~g}$ for $15 \mathrm{~min}$, and the pellets were resuspended into $2 \mathrm{ml}$ of cold PBS and transferred to Eppendorf tubes (Eppendorf Gerätebau GmbH, Hamburg, Federal Republic of Germany). To weaken the cell wall of the bacteria in these mixtures, cold reagent I ( $2 \mathrm{mg}$ of lysozyme per milliliter (Fluka AG, Chem Fabrik, Buchs, Sankt Gallen, Switzerland), $50 \mathrm{mM}$ glucose, 10 mM EDTA, and $20 \mathrm{mM}$ Tris- $\mathrm{HCl}$ ( $\mathrm{pH} \mathrm{8.0))} \mathrm{was} \mathrm{added,} \mathrm{and} \mathrm{the} \mathrm{mixtures}$ were incubated for $30 \mathrm{~min}$ at $0^{\circ} \mathrm{C}$. Complete cellular lysis was accomplished by the addition of cold reagent II ( $1 \%$ sodium dodecyl sulfate and $0.2 \mathrm{~N} \mathrm{NaOH}$ ). After $5 \mathrm{~min}$, cold reagent III ( $3 \mathrm{M}$ sodium acetate, $\mathrm{pH}$ 4.8) was added, and the mixture was incubated for an additional $60 \mathrm{~min}$ at $0^{\circ} \mathrm{C}$. After centrifugation at $5,000 \mathrm{~g}$ for $15 \mathrm{~min}$ at $0^{\circ} \mathrm{C}$, the chromosomal DNA, proteins, and high molecular weight RNA had been precipitated. Radioactivity associated with chromosomal DNA was measured in the sediment. The supernate, containing plasmid DNA, was first treated with cold ethanol at $-20^{\circ} \mathrm{C}$ for $30 \mathrm{~min}$ and then centrifuged at $5,000 \mathrm{~g}$ for $15 \mathrm{~min}$ at $0^{\circ} \mathrm{C}$. The sediment was dissolved in $0.1 \mathrm{M}$ sodium acetate- $0.05 \mathrm{M}$ Tris- $\mathrm{HCL}(\mathrm{pH} 8)$ and precipitated in cold ethanol for $30 \mathrm{~min}$. After centrifugation, the pellet, containing plasmid DNA was dissolved in $100 \mu \mathrm{l}$ of distilled water.
Isolation of chromosomal DNA. After the indicated incubation times, bacterial chromosomal DNA was isolated from vials 3-8 after disruption of leukocytes by distilled water, according to the method of Cosloy and Oishi (31).

Transformation by chromosomal DNA. E. coli AM $1095\left(\mathrm{Rec}^{+} \mathrm{Leu}^{-}\right)$ was transformed by chromosomal DNA isolated from E. coli PC2166 after phagocytosis of this strain by PMN and $M N$ in vials 3-8. The procedure used was a modification of the method described by Reynders et al. (32).

Briefly, the recipient cells were grown overnight in phosphate-buffered minimal salt medium at $37^{\circ} \mathrm{C}$. The culture was diluted 20 times with fresh prewarmed minimal medium and grown to an absorbance of 0.30 at $650 \mathrm{~nm}$. The cells were harvested by centrifugation and washed once in $20 \mathrm{ml}$ of $10 \mathrm{mM} \mathrm{NaCl}$ at $0^{\circ} \mathrm{C}$ and resuspended in $4 \mathrm{ml}$ of $20 \mathrm{mM}$ $N$-2-hydroxyethylpiperazine- $N^{\prime}-2$ ethane sulfonic acid per $\mathrm{NaOH}$ buffer, pH 6.0 at $0^{\circ} \mathrm{C}$. The recipient cells $(0.3 \mathrm{ml})$ were mixed with $0.1 \mathrm{ml}$ of donor DNA (final concentration $40-50 \mu \mathrm{g} / \mathrm{ml}$ ) and $0.1 \mathrm{ml}$ of a solution containing $150 \mathrm{mM} \mathrm{CaCl}_{2}$ and $130 \mathrm{mM} \mathrm{MgCl}_{2}$. The transformation mixture $(0.5 \mathrm{ml})$ was incubated for $10 \mathrm{~min}$ at $0^{\circ} \mathrm{C}$, followed by 6 min at $42^{\circ} \mathrm{C}$ and $60 \mathrm{~min}$ at $0^{\circ} \mathrm{C}$. Aliquots of $0.1 \mathrm{ml}$ were diluted with 30 $\mathrm{mM} \mathrm{CaCl}+26 \mathrm{mM} \mathrm{MgCl}$. Appropriate dilutions were placed on selective plates containing $1.7 \times 10^{-4} \mathrm{M} \mathrm{KH}_{2} \mathrm{PO}_{4}, 10^{-2} \mathrm{M} \mathrm{CaCl}_{2}$, and $10^{-2} \mathrm{M} \mathrm{MgCl}_{2}$. Leu ${ }^{+}$transformants were selected.

Transformation by plasmid DNA. Transformation by plasmid DNA isolated from $E$. coli PC2166 (RSF 1030) after various incubation times with PMN or MN was studied according to a modification of the method described by Cosloy and Oishi (31). E. coli $\mathrm{K} 12-\mathrm{C} 600$, used as an acceptor strain, was grown overnight at $37^{\circ} \mathrm{C}$ in L-broth ( $1 \%$ trypton, $0.5 \%$ yeast extract, and $0.5 \% \mathrm{NaCl}$ in distilled water). $4 \mathrm{ml}$ of this culture was transferred to $76 \mathrm{ml}$ of L-broth and incubated at $37^{\circ} \mathrm{C}$ for 90 min under aeration. After this time, the bacteria were adjusted to a final concentration of $10^{9} \mathrm{cfu} / \mathrm{ml}$. The culture was chilled and centrifuged in plastic tubes at $0^{\circ} \mathrm{C}$ for at least $1 \mathrm{~min}$ at $4,500 \mathrm{~g}$. The pellet was washed in 20 $\mathrm{ml}$ of cold $10 \mathrm{mM} \mathrm{NaCl}$. Care was taken that all subsequent manipulations were performed at $0^{\circ} \mathrm{C}$. After centrifugation at $4,500 \mathrm{~g}$ for 1 min, the cells were resuspended in $10 \mathrm{ml}$ of $75 \mathrm{mM} \mathrm{CaCl}_{2}$ dissolved in $10 \mathrm{mM} \mathrm{N}$-2-hydroxyethyl-piperazine- $N^{\prime}-2$ ethane sulfonic acid- $\mathrm{NaOH}$ buffer $\mathrm{pH}$ 6.0. In this way, competent cells were obtained ready for the transformation procedure. Then $0.3 \mathrm{ml}$ of competent cells were mixed gently in glass tubes with $0.1 \mathrm{ml}$ of plasmid DNA, isolated from vials 3-8 (see under Isolation of plasmid DNA). After $45 \mathrm{~min}$ of incubation at $0^{\circ} \mathrm{C}$, the mixtures were treated for $6 \mathrm{~min}$ at $42^{\circ} \mathrm{C}$ and afterwards chilled at $0^{\circ} \mathrm{C}$ for $30 \mathrm{~min}$.

A mixture of competent cells and plasmid DNA was diluted 10 times in L-broth and incubated for $60-120 \mathrm{~min}$ at $37^{\circ} \mathrm{C}$ under aeration. After centrifugation at $2,000 \mathrm{~g}$ for $10 \mathrm{~min}$, the cell pellet was dissolved in $1 \mathrm{ml}$ of L-broth, and $0.2 \mathrm{ml}$ of the samples was plated on solid media containing ampicillin $(40 \mu \mathrm{g} / \mathrm{ml})$. Competent $E$. coli K12-C600 without DNA added served as a control. After $18 \mathrm{~h}$ of growth at $37^{\circ} \mathrm{C}$, viable colonies (cfu) were counted and the frequency of transformants per viable recipient cells was calculated. To make sure that a linear relationship existed between DNA and the number of transformants also 1:2, diluted plasmid DNA suspensions were used.

Preparation of crude cell extracts and lysosomal granules containing acid DNases from PMN and MN leukocytes. Crude cell extracts and lysosomal granules were prepared according to methods modified from Beaufay et al. (33), Bornstein et al. (34), and Lamers et al. (21). PMN or $\mathrm{MN}\left(10^{7}\right.$ cells $\left./ \mathrm{ml}\right)$ were suspended into $1 \mathrm{ml}$ of ice-cold $0.15 \mathrm{M} \mathrm{KCl}$ solution (pH 7.0) containing $1 \mathrm{mM}$ EDTA, and sonicated six times for $20 \mathrm{~s}$ in a Branson sonifier. After centrifugation at $12,000 \mathrm{~g}$ for $20 \mathrm{~min}$, 
insoluble debris was removed and the supernate (fraction I) was studied for activity of acid DNases. The pellet was resuspended in KCl-EDTA solution and sonicated. The suspension was then centrifuged at 12,000 $\mathrm{g}$ for $20 \mathrm{~min}$, and the supernate (fraction II) was also studied for DNase activity. The amount of protein in cell extracts was determined by the method of Lowry et al. (35).

Lysosomal granules were prepared by suspending $10^{7} \mathrm{PMN}$ or $\mathrm{MN}$ into $1 \mathrm{ml}$ of isotonic sucrose $(0.23 \mathrm{M}$ sucrose, $10 \mathrm{mM}$ potassium acetate, $\mathrm{pH}$ 5.0). The suspension was homogenized in a potter homogenizer on ice. After sonication, the suspension was centrifuged for $5 \mathrm{~min}$ at 400 $g$, and the pellet was washed once with $1 \mathrm{ml}$ of isotonic sucrose and centrifuged again. The pellet was then resuspended in $0.15 \mathrm{M} \mathrm{KCl}, 0.1$ mM EDTA ( $\mathrm{pH}$ 7.0), and sonicated three times for $15 \mathrm{~s}$ (nuclear fraction). The supernate fractions were combined and centrifuged at $27,000 \mathrm{~g}$ for $30 \mathrm{~min}$. The pellet from this centrifugation, which was resuspended in $\mathrm{KCl}-\mathrm{EDTA}$ and sonicated, contained the lysosomal fraction; the supernate contained the cytosol. The nuclear, lysosomal, and cytosol fraction were tested separately for DNases activity.

Activity of acid DNases from PMN and MN. The activity of acid DNases in leukocyte fractions (fractions I and II, nuclear, lysosomal, and cytosol fraction) was studied by incubation of these fractions with chromosomal or with plasmid DNA isolated from E. coli PC2166 (RSF 1030). The reaction mixture in volume of $50 \mu \mathrm{l}$ contained $3 \mu \mathrm{g}$ of plasmid DNA or $2 \mu \mathrm{g}$ of chromosomal DNA, $0.1-20 \mu \mathrm{l}$ of leukocyte fractions (prepared from $10^{7} \mathrm{PMN}$ or MN), BSA (in a final concentration of $0.1 \mathrm{mg} / \mathrm{ml}$ ), $0.5 \mathrm{mM} \mathrm{MgCl}$, and $1 \mathrm{mM} \beta$-mercaptoethanol, $0.1 \mathrm{M}$ potassium acetate buffer (pH 4.8). The final $\mathrm{pH}$ of the mixture was 5.0. The same procedure was followed at pH 7.0 and 9.0 (instead of $0.1 \mathrm{M}$ potassium acetate buffer, $0.1 \mathrm{M}$ Tris- $\mathrm{HCl}$ buffer was used). After incubation for $60 \mathrm{~min}$ at $37^{\circ} \mathrm{C}$, samples $(50 \mu \mathrm{l})$ were subjected to $0.6 \%$ agarose-gel electrophoresis. Plasmid DNA treated with the leukocyte fractions for $0,5,30$, and 60 min was tested for transforming activity.

Agarose-gel electrophoresis. After incubation of leukocyte fractions prepared from PMN or MN with the plasmid or chromosomal DNA, samples were subjected to agarose-gel electrophoresis. Electrophoresis was carried out in horizontal slab gels (gel dimensions $14.5 \mathrm{~mm} \times 27$ $\mathrm{mm} \times 3 \mathrm{~mm}$ with 16 slots), containing $0.6 \%$ agarose (agarose type IV; Sigma Chemical Co., St. Louis, MO) dissolved in electrophoresis buffer ( $40 \mathrm{mM}$ Tris, $20 \mathrm{mM}$ sodium acetate $3 \mathrm{H}_{2} \mathrm{O}$, and $2 \mathrm{mM}$ EDTA adjusted to $\mathrm{pH} 7.8$ with acetic acid). Both agarose and electrophoresis buffer contained ethidium bromide in a final concentration of $2 \mu \mathrm{g} / \mathrm{ml}$. This plasmid and chromosomal DNA was electrophoresed either for $4 \mathrm{~h}$ at $30 \mathrm{~mA}$ or overnight at $12 \mathrm{~mA}$. Gels were photographed under ultraviolet light (360 nm) using Polaroid type film (Kodak 667; Eastman Kodak Co., Rochester, NY) with an orange 22 filter (Eastman Kodak Co.).

Electron microscopy. $1 \mathrm{ml}$ of opsonized E. coli PC2166 (RSF 1030) and $E$. coli $048: \mathrm{K} 1$ were incubated with $1 \mathrm{ml}$ of $\mathrm{PMN}$ at $37^{\circ} \mathrm{C}$ for 5 min. Phagocytosis was stopped by adding ice-cold PBS. Vials were centrifuged at $160 \mathrm{~g}$ for $5 \mathrm{~min}$, and pellets were washed three times with cold PBS, suspended in $0.3 \mathrm{ml}$ of gel-HBSS, and incubated for 5 and $60 \mathrm{~min}$. The PMN-bacteria interactions were terminated by mixing the suspensions with an equal volume of $0.5 \%$ glutaraldehyde in PBS at $0^{\circ} \mathrm{C}$. The mixtures were spun at $600 \mathrm{~g}$ for $5 \mathrm{~min}$. The supernates were removed and the pellets resuspended in $0.75 \mathrm{ml}$ of human plasma $\left(0^{\circ} \mathrm{C}\right)$ and were again spun at $600 \mathrm{~g}$ for $5 \mathrm{~min}$. The supernates were removed and pellets overlaid with additional glutaraldehyde buffer fixative (3\% glutaraldehyde, $2 \%$ formaldehyde, and $0.1 \%$ acroleine in $0.1 \mathrm{M}$ phosphate buffer, $\mathrm{pH} 7.0$ at $0^{\circ} \mathrm{C}$ ) for $60 \mathrm{~min}$. The pellets were then washed twice with $0.1 \mathrm{M}$ phosphate buffer at $0^{\circ} \mathrm{C}$ and stored in this same buffer overnight at $4^{\circ} \mathrm{C}$. Further processing for electron microscopy included postfixation for $60 \mathrm{~min}$ in $2 \mathrm{ml}$ of $1 \%$ osmium tetraoxide in phosphate buffer. Pellets were then dehydrated in a graded series of ethanol washes and propylene oxide. The pellets were embedded in epon and cut with an LKB ultratome III (LKB Instruments, Inc., Stockholm, Sweden) equipped with a diamond knife. Sections were stained with $4 \%$ uranylacetate and lead citrate and were examined in a Carl Zeiss 109 electron microscope (Carl Zeiss, Oberkochen/Württemberg, Federal Republic of Germany).

\section{Results}

Phagocytosis and killing of E. coli PC2166 (RSF 1030) and E. coli 048:KI by PMN and MN. Because no significant opsonization occurred in normal serum, the encapsulated $E$. coli 048: $\mathrm{K} 1$ was opsonized in $20 \%$ hyperimmune rabbit serum (this serum concentration did not effect viability of the bacteria); the unencapsulated $E$. coli strain PC2166 (RSF 1030) was opsonized in $2.5 \%$ human pooled serum. These opsonized bacteria were incubated with PMN or MN and the uptake of the bacteria by the leukocytes was measured. After 5 min of incubation, 70$80 \%$ of the E. coli $\mathrm{PC} 2166$ (RSF 1030) and $50-60 \%$ of the $E$. coli $048: \mathrm{K} 1$ was taken up by $\mathrm{PMN}$, compared with $50-60 \%$ of the E. coli $\mathrm{PC} 2166$ (RSF 1030) and $40-50 \%$ of the E. coli 048:K1 by MN (data not shown).

In the next experiment, PMN or MN were incubated for 5 min with opsonized bacteria, and the phagocytes were then washed free of nonassociated bacteria and further incubated. The number of viable bacteria within the phagocytes was measured at indicated time points (Fig. 1). The rate of killing of the bacteria by PMN and MN was fast during the first $5 \mathrm{~min}$, and $>99 \%$ of the bacteria were killed. The unencapsulated $E$. coli was killed more readily than the encapsulated strain. Killing by PMN was more efficient than that by $\mathrm{MN}$.

Release of radioactivity from $\left[{ }^{3} \mathrm{H}\right]$ thymidine-labeled bacteria after phagocytosis by PMN and MN. To measure degradation of bacterial DNA within phagocytes, bacteria and PMN or $\mathrm{MN}$ were incubated for $5 \mathrm{~min}$, washed and further incubated for 30, 60, 120, and $240 \mathrm{~min}$. After these time intervals, PMN and $\mathrm{MN}$ were lysed in distilled water. Over $90 \%$ of the radioactivity could be pelleted after centrifugation of disrupted PMN

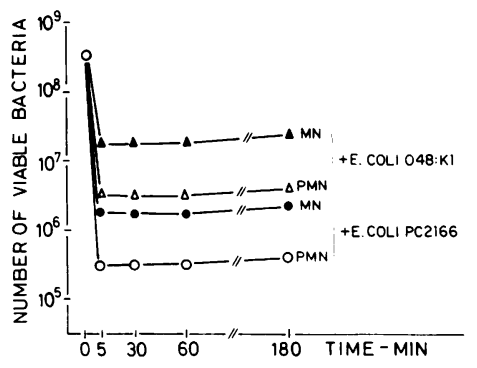

Figure 1. Killing of E. coli PC2166 (RSF 1030) and $E$ coli $048: \mathrm{K} 1$ by $\mathrm{PMN}$ and MN. E. coli $\mathrm{PC} 2166$ (RSF 1030) opsonized in $2.5 \%$ human pooled serum (O), and $E$. coli $048: \mathrm{K} 1$ opsonized in $20 \%$ rabbit antiserum $(\triangle)$ were incubated with $\mathrm{PMN}$ or $\mathrm{MN}$ at $37^{\circ} \mathrm{C}$ for $5 \mathrm{~min}$. The leukocytes were washed free of bacteria not associated with phagocytes. The $\mathrm{PMN}$ and $\mathrm{MN}$ with associated bacteria were further incubated for 0 , 30,60 , and $180 \mathrm{~min}$. After the indicated times, the leukocytes were disrupted and the number of viable leukocyte-associated bacteria was determined by a pour-plate technique. 
with phagocytized bacteria at $12,000 \mathrm{~g}$ for $15 \mathrm{~min}$. This shows that in PMN the great majority of the radioactivity remained bacteria-associated and that in PMN no substantial disruption of the bacterial DNA occurred (Fig. $2 A$ ). In contrast, when $\mathrm{MN}$ were lysed after phagocytosis of the unencapsulated $E$. coli strain PC2166 (RSF 1030), 50-60\% of the radioactivity was released from the bacterial DNA into the medium after 2-3 h of incubation and could not be pelleted after centrifugation. About $30-40 \%$ of the released radioactivity was TCA soluble. However, when $\mathrm{MN}$ had phagocytized the encapsulated $E$. coli bacteria, no release of radioactivity was observed (Fig. $2 A$ ).

From these experiments one might conclude that $\mathrm{MN}$ contain DNases that can degrade DNA of unencapsulated and not of encapsulated strains. However, it is also possible that when encapsulated bacteria are phagocytized, the $K$ antigen of these bacteria prevent the DNases from reaching the DNA, and that in PMN, DNases are not able to reach DNA from either kind of bacteria. Therefore, pancreas DNase I or bovine spleen DNase II was added to the PMN and MN lysate after these cells had phagocytized E. coli PC2166 (RSF 1030) or E. coli 048:K1 (Fig. $2 B$ ). When these enzymes were added to the PMN lysate, a

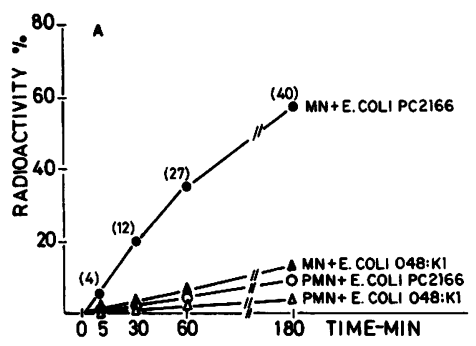

Figure 2. (A) Release of radioactivity from $\left[{ }^{3} \mathrm{H}\right]$ thymidine-labeled $E$. coli $\mathrm{PC} 2166$ and $E$. coli 048:K1 phagocytized by $\mathrm{PMN}$ and MN. Opsonized E. coli $\mathrm{PC} 2166(0)$ and $E$. coli 048: $\mathrm{K} 1(\triangle)$ were incubated with $\mathrm{PMN}$ or $\mathrm{MN}$ at $37^{\circ} \mathrm{C}$. After $5 \mathrm{~min}$, the leukocytes were washed free of bacteria not associated with phagocytes. The PMN and MN with associated bacteria were further incubated for $0,30,60$, and $180 \mathrm{~min}$. After the indicated times the leukocytes were disrupted and centrifuged at $12,000 \mathrm{~g}$ for $15 \mathrm{~min}$. The pellets and the supernates

were individually resuspended in scintillation liquid, and the percentage of radioactivity released into the supernate was calculated. Numbers in brackets indicate percentage of TCA-soluble radioactivity. $(B)$ Release of radioactivity from $\left[{ }^{3} \mathrm{H}\right]$ thymidine-labeled $E$. coli $\mathrm{PC} 2166$ (RSF 1030) and E. coli 048:K1 phagocytized by PMN and MN after addition of bovine pancreas DNase. Opsonized E. coli PC2166 (o) and $E$. coli $048: \mathrm{K} 1(\Delta)$ were incubated with $\mathrm{PMN}$ or $\mathrm{MN}$ at $37^{\circ} \mathrm{C}$. After $5 \mathrm{~min}$, the leukocytes were washed free of bacteria not associated with phagocytes and further incubated for $0,5,30,60$, and $180 \mathrm{~min}$. At indicated time intervals, the leukocytes were disrupted and bovine pancreas DNase was added (final concentration $0.5 \mathrm{mg}$ / $\mathrm{ml}$ in $0.1 \mathrm{M}$ potassium-acetate buffer, $\mathrm{pH}$ 4.9). After $15 \mathrm{~min}$ of incubation, radioactivity released into the supernatant was measured.

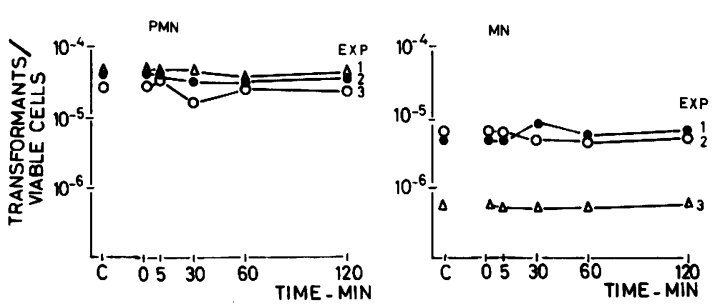

Figure 3. Frequency of transformation of competent E. coli K12C600 by plasmid DNA isolated after various time intervals of phagocytosis of E. coli PC2166 (RSF 1030) by PMN and by MN. Opsonized $E$. coli $\mathrm{PC} 2166$ (RSF 1030) was incubated with PMN and MN at $37^{\circ} \mathrm{C}$ for $5 \mathrm{~min}$; the leukocytes were washed free of bacteria not associated with phagocytes and further incubated for $0,30,60$ and $120 \mathrm{~min}$. At indicated time intervals, plasmid DNA was isolated from the bacteria within phagocytes. Competent $E$. coli K12-C600 was transformed by isolated plasmids and the frequency of transformants per viable recipient cells was calculated. Plasmid DNA isolated from E. coli PC2166 (RSF 1030) not exposed to MN or PMN served as a control (C).

rapid increase in released radioactivity was observed when unencapsulated $E$. coli bacteria had been phagocytized. A slower increase in release of radioactivity was observed when MNs were used. A maximum of $70-80 \%$ of the radioactivity was released; with PMN, this value was reached after 30-60 min; with $\mathrm{MN}$, this level was reached after $180 \mathrm{~min}$. In contrast, no increase in amount of released radioactivity was measured when pancreas DNase I or bovine spleen DNase II was added to a lysate of PMN or MN that had phagocytized encapsulated $E$. coli 048:K1. These results show that when PMN have phagocytized unencapsulated bacteria, bacterial DNA is not protected against the action of DNases because exogenous enzymes are able to degrade the bacterial DNA. The results also suggest that (a) PMN do not contain DNase or only in very low amounts, and $(b)$ the cell envelope of $E$. coli $048: \mathrm{K} 1$ prevents the breakdown of DNA by the DNase of MN. The latter observation was confirmed by electron microscopy (data not shown).

Effect of PMN and MN on biological activity of chromosomal and plasmid DNA. The questions remain whether degradation of bacterial DNA by MN also affects the ability of bacterial DNA to transform acceptor bacteria, and whether the absence of any detectable degradation in PMN also means that DNA from bacteria phagocytized by PMN retains its biological function. Therefore, PMN and MN were incubated with $E$. coli strains PC2166 (RSF 1030) for 5 min, washed free of uningested bacteria, and further incubated. At different time intervals, plasmid DNA was isolated from the bacteria within the PMN or $\mathrm{MN}$, and the number of transformants was measured when the fractions were incubated with the competent recipient $E$. coli $\mathrm{K} 12-\mathrm{C} 600$. Virtually no decrease was seen in the number of transformants induced by plasmid DNA isolated at different time points from bacteria within PMN or MN (Fig. 3). There was a $50 \%$ decrease in the number of transformants when diluted (1:2) plasmid DNA was used (data not shown). 


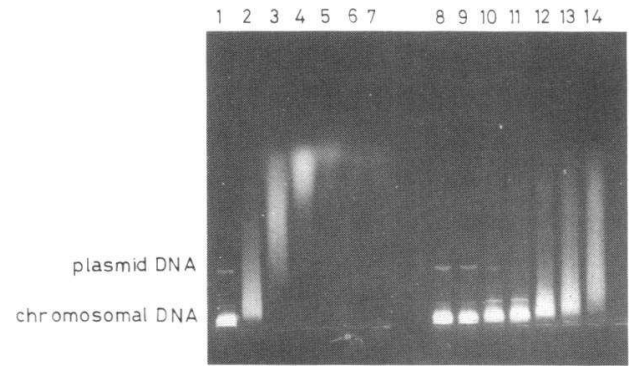

Figure 4. DNase activity of cell lysates prepared from $M N$ and PMN. Chromosomal and plasmid DNA isolated from E. coli PC2166 (RSF 1030 ) were incubated with different volumes of cell lysates prepared from $\mathrm{MN}$ and PMN $\left(10^{7}\right.$ cells $\left./ \mathrm{ml}\right)$ for $60 \mathrm{~min}$ at $37^{\circ} \mathrm{C}$. The final $\mathrm{pH}$ of the mixture was 5.0. After this incubation, samples of $50 \mu \mathrm{l}$ were subjected to $0.6 \%$ agarose-gel electrophoresis. (I) control DNA; (2-7) DNA incubated with lysate from MN (volumes: $0.1,0.5,1,5,10$, and $20 \mu \mathrm{l}) ;(8)$ control DNA; (9-14) DNA incubated with lysate from PMN (the same volumes were used as in the experiment with lysate from $\mathrm{MN}$ ).

Also, chromosomal DNA was isolated from bacteria that had been phagocytized by PMN or MN, and the number of transformants was measured after incubation of this DNA with recipient cells. With chromosomal DNA isolated from bacteria phagocytized by PMN for $1 \mathrm{~h}, 432$ transformants were seen, compared with only 14 transformants with chromosomal DNA isolated from bacteria phagocytized by MN (Table I).

Partial isolation of acid DNases from PMN and MN. To evaluate whether acid DNases are responsible for the degradation of DNA during phagocytosis by $\mathrm{MN}$, cell fractions were prepared from MN and for comparison from PMN (1 ml of lysate prepared from $10^{7} \mathrm{MN}$ contained $0.278 \mathrm{mg}$ of protein, and $1 \mathrm{ml}$ of lysate prepared from $10^{7} \mathrm{PMN}$ contained $0.162 \mathrm{mg}$ of protein). These fractions were incubated with chromosomal and plasmid DNA

Table I. Transformation by Chromosomal DNA Isolated from E. Coli PC2166 (RSF 1030) after Phagocytosis by PMN and MN

\begin{tabular}{llc}
\hline & \multicolumn{2}{l}{$\begin{array}{l}\text { No. of transformants by chromosomal } \\
\text { DNA isolated from } E \text {. coli PC2166 } \\
\text { (RSF 1030) ingested by }\end{array}$} \\
\cline { 2 - 3 } $\begin{array}{l}\text { Incubation time (min) } \\
\text { with PMN or MN }\end{array}$ & PMN & MN \\
\hline 0 & $480 / 460$ & $350 / 370$ \\
5 & $450 / 438$ & $330 / 312$ \\
60 & $417 / 432$ & $14 / 12$
\end{tabular}

Opsonized E. coli was incubated with $\mathrm{PMN}$ or $\mathrm{MN}$ at $37^{\circ} \mathrm{C}$. After 5 min PMN and MN were washed free of bacteria not associated with the phagocytes. The PMN and MN with associated bacteria were further incubated for $60 \mathrm{~min}$. E. coli AM $1095\left(\mathrm{Rec}^{+} \mathrm{Leu}^{-}\right)$was transformed by chromosomal DNA isolated after the indicated times and the number of transformants (two experiments) was measured.

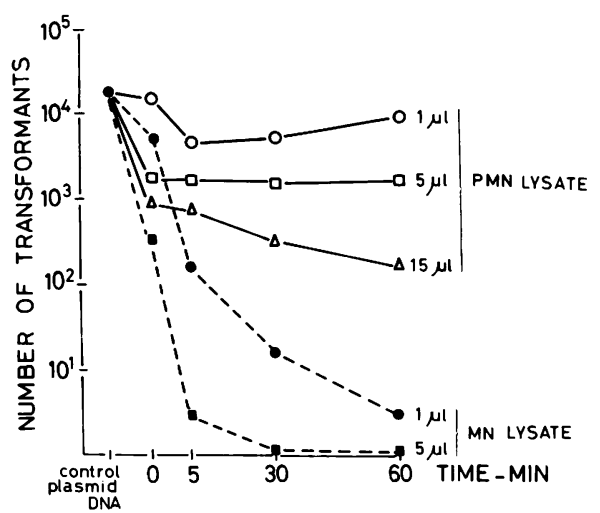

Figure 5. Transformability of plasmid DNA after treatment for various time intervals with leukocyte lysates prepared from PMN and MN. $3 \mu \mathrm{g}$ of plasmid DNA isolated from E. coli PC2166 (RSF 1030) was incubated for $0,5,30$, and $60 \mathrm{~min}$ with 1 or $5 \mu \mathrm{l}$ (of PMN lysate, $1 \mathrm{ml}$ contained $0.162 \mathrm{mg}$ protein) and 1 or $5 \mu \mathrm{l}$ of $\mathrm{MN}$ lysate ( $1 \mathrm{ml}$ contained $0.278 \mathrm{mg}$ of protein). After the indicated incubation times, the plasmids were used to transform competent acceptor bacteria.

of $E$. coli. After this incubation, degradation of DNA was measured by agarose-gel electrophoresis and by determining the ability of the DNA to transform recipient cells. Surprisingly, in the lysates from both PMN and MN, acid DNase activity was found. However, the activity in lysates from $M N$ was at least 15-20-fold higher (Fig. 4). Similar results were obtained when lysate-treated plasmid DNA was used to transform recipient cells (Fig. 5). The DNase activity was evident only when the $\mathrm{pH}$ of the reaction mixture was between 4.9-5. At pH 7 and pH 9, the DNase had lost their ability to degrade plasmid and chromosomal DNA, and no effect on DNA was observed by gel electrophoresis.

Degradation of bacterial DNA by PMN and MN from a patient with $C G D$. To study any possible difference in degra-

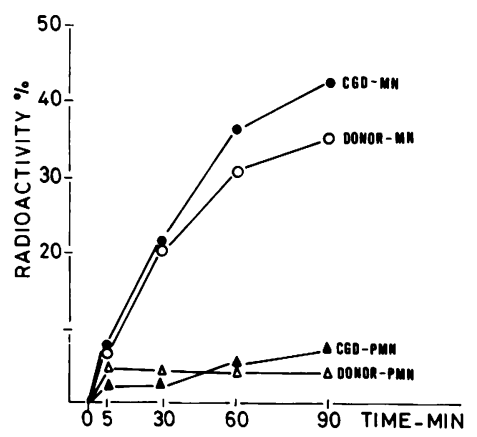

Figure 6. Release of radioactivity from [ ${ }^{3} \mathrm{H}$ ]thymidine-labeled $E$. coli PC2166 (RSF 1030) after phagocytosis by PMN and $\mathrm{MN}$ isolated from a healthy donor and from a patient with CGD. Opsonized E. coli PC2166 (RSF 1030) were incubated with PMN and MN. After 5 min, the leukocytes were washed free of bacteria not associated with phagocytes and further incubated for $0,30,60$, and $90 \mathrm{~min}$. After indicated times, the phagocytosis mixtures were centrifuged at $12,000 \mathrm{~g}$ for $15 \mathrm{~min}$. The pellets and the supernates were individually resuspended in scintillation liquid, and the percentage of radioactivity released into the supernate was calculated. 
dation of bacterial DNA during phagocytosis by PMN and MN isolated from healthy donors and from a patient with CGD, PMN and MN from these individuals were lysed in distilled water after phagocytosis of radiolabeled E. coli PC2166 (RSF 1030). The lysates were centrifuged at $12,000 \mathrm{~g}$ for $15 \mathrm{~min}$ and the amount of radioactivity in the medium was measured. There was no difference in the rate of release of radioactivity between PMN or MN from healthy donors and these from CGD patients (Fig. 6). After 90 min of phagocytosis by PMN 10\%, and after 90 min of phagocytosis by $\mathrm{MN} \sim 40 \%$, of the radioactivity had been released into the medium.

\section{Discussion}

Sufficiently opsonized $E$. coli bacteria are rapidly phagocytized and killed by PMN and MN. It is often assumed that most microorganisms are digested after killing and that bacterial components are rapidly degraded by the extensive granule-associated armament of degradative enzymes (36-39). However, evidence showing that molecular degradation of ingested microorganisms is an integral part of the function of phagocytes in host defense is limited. Only few studies have been published with biochemical evidence of microbial degradation during and after phagocytosis $(18-20)$. Using $\left[{ }^{32} \mathrm{P}\right]$ or $\left[{ }^{14} \mathrm{C}\right]$ glucose-labeled $E$. coli strains Cohn (18) showed release of acid soluble radioactivity during ingestion by both PMN and macrophages, indicating that protein, RNA, and peptidoglycan were degraded. RNA was degraded more rapidly than DNA. Patriarca et al. (20) and Elsbach et al. (19), using $E$. coli with specifically labeled constituents without serum added, found a comparable degradation by rabbit PMN. This reaction reached a plateau after $1 \mathrm{~h}$, at which time $\sim 50 \%$ of the labeled bacterial protein, RNA, and peptidoglycan had been converted into acid soluble products; $\sim 10 \%$ of the ${ }^{14} \mathrm{C}$ fatty acid-labeled phospholipids had been hydrolyzed, and no degradation of DNA was observed.

We studied phagocytosis by human PMN or MN of $E$. coli strains with different structures of their cell envelopes. All bacteria were incubated in serum before adding to the phagocytes. In the mixtures of PMN or MN and opsonized bacteria, no free serum was present. In this standardized system we showed that, although phagocytosis and killing by human MN was less efficient than that of human PMN, MN and not PMN were able to rapidly degrade bacterial DNA. However, only DNA from an unencapsulated strain was degraded by the $\mathrm{MN}$. When an encapsulated strain was ingested by $\mathrm{MN}$, no appreciable degradation of DNA was observed. One could ask whether our assay with radiolabeled bacteria really shows ingestion of encapsulated bacteria and not merely attachment to the phagocyte membrane, and argue that the absence of ingestion might be the reason of the inefficient DNA degradation. However, using electron microscopy, we have found that nearly all MN-associated bacteria are internalized by the MN (data to be published). Moreover, most of the MN-associated bacteria were killed, indicating that these bacteria were subject to the bactericidal ac- tivity of the MN. It is more likely, therefore, that the $\mathrm{K}$ antigen of the encapsulated $E$. coli protected the bacterial DNA from attack by the MN enzymes. This is also indicated by the fact that addition of pancreas DNase to a lysate of $\mathrm{MN}$ with encapsulated bacteria did not induce release of DNA fragments. Presumably, $\mathrm{K}$ antigen of encapsulated $E$. coli strains is resistant against the digestive forces of the $\mathrm{MN}$, so that exogenous DNase cannot penetrate into the cytoplasma to degrade bacterial DNA. Electronmicroscopically, it was shown that indeed, encapsulated bacteria were much more resistant against digestion by phagocytes than the unencapsulated strains.

About $40 \%$ of DNA from the unencapsulated $E$. coli strains was degraded to acid-soluble fragments that are smaller in size than 10-16 nucleotides (29). Interestingly, no degradation of plasmid DNA was observed. Therefore, all the DNA fragments observed must have been breakdown product of chromosomal DNA. Plasmids isolated from bacteria ingested by PMN or MN were still able to transform competent recipient bacteria. This indicates that the genes located on the plasmid and responsible for antimicrobial resistance remained intact over a long period, despite the facts that the bacteria harboring the plasmids were ingested and killed by PMN or MN and that chromosomal DNA was degraded by MN. Similar results were seen when serum-sensitive bacteria were incubated in serum in the absence of phagocytes (39a).

DNase activity in $\mathrm{MN}$ has also been shown by Lamers et al. (21), Eschenbach (40, 41), and Bornstein et al. (34). Lamers et al. (21) observed degradation of DNA-anti-DNA complexes in MN but not in PMN. These authors reported that human PMN does not contain DNases, whereas human MN does. We confirmed the observation that DNA was not degraded by PMN. Nevertheless, we detected some DNase activity in lysates of PMN.

DNA was only degraded when the $\mathrm{pH}$ was between 4.9 and 5.0. No breakdown of DNA was observed when the $\mathrm{pH}$ was 7.0 or 9.0 . When it is assumed that breakdown of bacterial DNA occurs in the phagosomes of the $\mathrm{MN}$, the $\mathrm{pH}$ in the vacuoles must be $\sim 5.0$. Although unlikely, it remains possible that while the $\mathrm{pH}$ in the phagosomes of $\mathrm{MN}$ is $\sim 4.9-5.0$, the $\mathrm{pH}$ in the phagosomes of PMN is above 5.0, which would render the acid DNases inactive. Since the rate of breakdown of bacterial DNA by MN obtained from a patient with CGD was exactly the same as that by normal control $\mathrm{MN}$, it is likely that also in the phagosome of CGD MN, the $\mathrm{pH}$ is $\sim 5.0$. Because PMN and MN from CGD patients are not able to mount a respiratory burst, and no toxic oxygen species are produced $(42,43)$, our findings also imply that these toxic oxygen species do not contribute to the rate of degradation of DNA. Further studies on the effect of oxygen species on DNA are needed to clarify the mechanism of DNA degradation.

Friedlander (44) has reported that DNA release could be used as a direct measure of microbial killing by phagocytes. He incubated peripheral blood leukocytes with $\left[{ }^{14} \mathrm{C}\right]$ thymidine-labeled Salmonella typhimurium in presence of homologous 
serum, and it appeared that after $2-4 \mathrm{~h}, 32-59 \%$ of the radioactivity was released and $63-75 \%$ was released after $18 \mathrm{~h}$. Inactivated leukocytes (heated to $56^{\circ} \mathrm{C}$ for $20 \mathrm{~min}$ ) released $<5 \%$ of the radioactivity. Friedlander concluded that the release of radioactivity paralleled phagocytosis and killing of bacteria by peripheral blood leukocytes. He suggested to measure release of radioactivity as an assay for phagocytic cell function. Because we observed only digestion of DNA by MN, Friedlander's findings are partially in contrast to ours. It is possible that $S$. $t y$ phimurium is susceptible to the low activity of DNase present in PMN, but it is more likely that in a mixture of PMN and MN, MNs are responsible for the release of DNA and that his method can only be used as a measure of bacterial killing by $\mathrm{MN}$ or only when certain bacteria are used.

The relevance of our findings is not known. In any event, it means that while bacteria ingested by $\mathrm{MN}$ and PMN are rapidly killed, and chromosomal DNA is degraded by $\mathrm{MN}$, plasmid with genes responsible for drug-resistance remain biologically intact. Whether the presence in the host of these plasmids contributes to the increase in strains that are resistant to antimicrobial agents remains to be proven.

\section{Acknowledgments}

We thank Mrs. G. M. Vleugel-Klarenbeek, H.-J. Harmstra and T. F. J. Martens for excellent technical assistance, Mrs. E. M. Zuidweg for performing the assay of chromosomal transformation, and Mrs. M. E. Hoeneveld for her secretarial assistance in the preparation of this manuscript. We are indebted to Dr. D. Roos for this helpful criticism of the manuscript and to Prof. dr. J. J. Geuze for help with the electron microscopy.

\section{References}

1. Goldman, J. N., S. Ruddy, K. F. Austen, and D. S. Feingold. 1969. The serum bactericidal reaction. III. Antibody and complement requirements for killing a rough Escherichia coli. J. Immunol. 102:1379_ 1387.

2. Bladen, H. A., R. T. Evans, and S. E. Mergenhagen. 1966. Lesions in Escherichia coli membranes after action of antibody and complement. J. Bacteriol. 91:2377-2381.

3. Klebanoff, S. J. 1975. Antimicrobial systems of the polymorphonuclear leukocyte. In The Phagocytic Cell in Host Resistance. J. A. Bellanti and D. H. Dayton, editors. Raven Press, New York. 45-59.

4. Stossel, T. P. 1974. Phagocytosis (second of three parts). N. Engl. J. Med. 290:774-780.

5. Stossel, T. P. 1974. Phagocytosis (first and third part). N. Engl. J. Med. 290:717-723, 833-839.

6. Stossel, T. P. 1975. Phagocytosis: recognition and ingestion. Semin. Hematol. 12:83-116.

7. Stossel, T. P. 1978. How do phagocytes eat? Ann. Intern. Med. 89:398-402.

8. Wilkinson, P. C. 1976. Recognition and response in mononuclear and granular phagocytes. A review. Clin. Exp. Immunol. 5:355-366.

9. Babior, B. M. 1978. Oxygen-dependent microbial killing by phagocytes. I. N. Engl. J. Med. 298:659-668.

10. Babior, B. M. 1978. Oxygen-dependent microbial killing by phagocytes. II. N. Engl. J. Med. 298:721-725.
11. Klebanoff, S. J., and R. A. Clark. 1978. The neutrophil function and clinical disorders. North-Holland Publishing Co., Amsterdam. 408466.

12. Hirsch, J. G., and Z. A. Cohn. 1960. Degranulation of polymorphonuclear leukocytes following phagocytosis of microorganisms. J. Exp. Med. 112:1005-1022.

13. DeDuve, C., and R. Wattigux. 1966. Functions of lysosomes. Annu. Rev. Physiol. 28:435-493.

14. Lahav, M., N. Ne'emay, E. Adler, and I. Ginsburg. 1974. Effect of leukocyte hydrolases on bacteria. I. Degradation of C-labeled streptococcus and staphylococcus by leukocyte lysates in vitro. J. Infect. Dis. 129:528-537.

15. Devoe, J. W., D. W. Storm, and J. E. Gilchrist. 1973. A study on phagocytosis and on structural events during intracellular degradation. Can. J. Microbiol. 19:525-530.

16. Spitznagel, J. K., and L. A. Wilson. 1966. Normal serum toxicity for $\mathrm{P}^{32}$-labeled smooth enterobacteriaceae. I. Loss of label, death, and ultrastructural damage. J. Bacteriol. 9:393-400.

17. Friedlander, A. M. 1975. DNA release as a direct measure of microbial killing. I. Serum bactericidal activity. J. Immunol. 115:14041408.

18. Cohn, Z. A. 1963 . The fate of bacteria within phagocytic cells. J. Exp. Med. 117:27-42.

19. Elsbach, P., O. Pettis, S. Beckerdite, and R. Franson. 1973. Effect of phagocytosis by rabbit granulocytes on macromolecular synthesis and degradation in different species of bacteria. J. Bacteriol. 115:490-497.

20. Patriarca, P., S. Beckerdite, P. Pettis, and P. Elsbach. 1972. Phospholipid metabolism by phagocytic cells. VII. The degradation and utilization of phospholipids of various microbial species by rabbit granulocytes. Biochim. Biophys. Acta. 280:45-56.

21. Lamers, M. C., E. R. de Groot, and D. Roos. 1981. Phagocytosis and degradation of DNA-anti-DNA complexes by human phagocytes. I. Assay conditions, quantitative aspects and differences between human blood monocytes and neutrophils. Eur. J. Immunol. 11:757-764.

22. Glynn, A. A., and C. J. Howard. 1970. The sensitivity to complement of strains $E$. coli related to their $\mathrm{K}$ antigens. Immunology. 18:331-346.

23. Robbins, J. B., G. H. McCracken, G. E. Gotschlich, F. Orkskov, I. Orkskov, and L. A. Hanson. 1974. Escherichia coli K1 capsular polysaccharide associated with neonatal meningitis. N. Engl. J. Med. 290:1216-1219.

24. Verhoef, J., P. K. Peterson, and P. G. Quie. 1977. Kinetics of staphylococcal opsonization, attachment, ingestion and killing by human polymorphonuclear leukocytes: a quantitative assay using $\left[{ }^{3} \mathrm{H}\right]$ thymidinelabeled bacteria. J. Immunol. Methods. 14:303-311.

25. Kayser, B., J. Holmgren, and L. A. Hanson. 1972. The protective effect against $E$. coli of $\mathrm{O}$ and $\mathrm{K}$ antibodies of different immunoglobulin classes. Scand. J. Immunol. 1:27-32.

26. Cambell, D. H., J. S. Garvey, N. E. Cremer, and D. H. Sussdorf. 1964. Antigen antibody reactions. In Methods in Immunology. W. A Benjamin, Inc. New York and Amsterdam, Second ed. 166-167.

27. Rissing, J. P., T. M. Buxton, W. L. Moore, T. Ozwa, and W. L. Moore, Jr. 1978. Enzyme-linked immunospecific antibody test for detecting antibody to Klebsiella. J. Clin. Microbiol. 8:704-707.

28. Böyum, A. 1968. Isolation of mononuclear cells and granulocytes from human blood. Scand. J. Clin. Lab. Invest. Suppl. 97:77-89.

29. Cleaver, J. E., and H. W. Boyer. 1972. Solubility and dialysis limits of DNA oligonucleotides. Biochim. Biophys. Acta. 262:116-124.

30. Birnboim, H. C., and J. Doly. 1979. A rapid alkaline extraction procedure for screening recombinant plasmid DNA. Nucleic Acids Res. 7:1513-1523. 
31. Cosloy, S. D., and M. Oishi. 1973. The nature of the transformation process in Escherichia coli K12. Mol. Gen. Genet. 124:1-10.

32. Reynders, B., W. P. M. Hoekstra, H. E. N. Bergmans, and J. M. van Die. 1978. Transformation in Escherichia coli. Proc. Eur. Bacterial Transformation Transfection, 4th, Oxford, England. 113-121.

33. Beaufay, H., D. S. Bendall, P. Baudhuid, and C. De Duve. 1959 Intracellular distribution of some dehydrogenases, alkaline deoxyribonuclease and iron in rat-liver tissue. Biochem. J. 73:623-628.

34. Bornstein, D. L., A. N. Weinberg, and M. N. Swartz. 1966. A deoxyribonuclease from rabbit leukocytes. Proc. Soc. Exp. Biol. Med. 121:677-681.

35. Lowry, O. H., N. J. Rosebrough, A. Lewis Farr, and R. J. Randall. 1952. Protein measurement with the folin phenol reagent. J. Biol. Chem. 193:265-275.

36. Hirschhorn, R. 1974. Lysosomal mechanism in the inflammatory process. In The Inflammatory Process. B. W. Zweifach, L. Grant, and R. T. McCluskey, editors. Academic Press, New York. Vol. I:259-285.

37. Elsbach, P. 1974. Phagocytosis. In The Inflammatory Process. B. W. Zweifach, L. Grant, and R. T. McCluskey, editors. Academic Press, New York. Vol. I:363-408.

38. Hirsch, J. G. 1974. Neutrophil leukocytes. In The Inflammatory Process. B. W. Zweifach, L. Grant, and R. T. McCluskey, editors. Academic Press, New York. Vol. I:411-447.

39. Steinman, R. M., and Z. A. Cohn. 1974. The metabolism and physiology of the mononuclear phagocytes. In The Inflammatory Process. B. W. Zweifach, L. Grant, and R. T. McCluskey, editors. Academic Press, New York. Vol. I:447-510.

39a. Rozenberg-Arska, M., E. C. Salters, J. A. G. van Strÿp, W. P. M. Hoekstra, and J. Verhoef. 1984. Degradation of Escherichia coli chromosomal and plasmid DNA in serum. J. Gen. Microbiol. 130:217-222.

40. Eschenbach, C. 1971. Cytochemischer Nachweis von saurer Deoxyribonuclease im Cytoplasma von Blutzellen. II. Activität der sauren Deoxyribonuclease im Cytoplasma von Leukocyten während akuter Infectionen. Klin. Wochenschr. 49:949-957.

41. Eschenbach, C. 1971. Cytochemischer Nachweis von saurer Deoxyribonuclease im Cytoplasma von Blutzellen. III. Activität der sauren Deoxyribonuclease im Cytoplasma von Leukocyten akuter Leukosen im Kindesalter. Klin. Wochenschr. 49:958-968.

42. Holmes, B., A. R. Page, and R. A. Good. 1967. Studies of the metabolic activity of leukocytes from patients with a genetic abnormality of phagocytic function. J. Clin. Invest. 46:1422-1432.

43. Curnutte, J. T., D. M. Whitten, and B. M. Babior. 1974. Defective superoxide production by granulocytes from patients with chronic granulomatous disease. $N$. Engl. J. Med. 290:593-597.

44. Friedlander, A. M. 1978. DNA release as a direct measure of microbial killing by phagocytes. Infect. Immun. 22:148-154. 